\title{
Work-related values and organizational values from the perspective of university professors: A correlational study
}

\author{
Valores relativos ao trabalho e valores organizacionais \\ na perspectiva de professores universitários: \\ um estudo correlacional
}

\author{
Juliana Ribeiro Serravalle CÂMARA ${ }^{1}$ \\ Camila de Sousa PEREIRA-GUIZZO²
}

\begin{abstract}
The alignment of personal and organizational values can positively influence performance. Considering the motivational aspect of these values, organizations and workers seek to satisfy their goals and needs through work. Thus, the study of personal and organizational values of university professors can contribute to the production of science, technology and innovation through committed professionals with this strategic axis. The aim of the present study was to evaluate work-related values and their relationship with organizational values. Sixty-eight professors from an institution of higher education, which focuses on innovation, participated in the study. The results showed that Realization at Work was the factor with the highest score; Social Relationships showed correlations with the organizational values Autonomy $(p=0.018)$, Realization $(p=0.001)$, Mastery $(p=0.048)$, Prestige $(p=0.001)$, Conformity $(p=0.016)$ and Concern with Community $(p=0.014)$. These results suggest the importance of values for satisfaction at work and organizational strategies.
\end{abstract}

Keywords: Creativity; High education; Innovation; Job satisfaction; Organizational climate.

\section{Resumo}

O alinhamento dos valores pessoais e organizacionais pode influenciar positivamente o desempenho profissional. Considerando o aspecto motivacional desses valores, organizações e trabalhadores buscam a satisfação de suas metas e necessidades por meio do trabalho. Nesse sentido, o estudo dos valores pessoais e organizacionais do professor pode contribuir para a produção de ciência, tecnologia e inovação por meio de profissionais engajados com esse eixo estratégico. O objetivo do estudo foi avaliar os valores relativos ao trabalho e sua relação com os valores organizacionais.

\footnotetext{
$\boldsymbol{v} \mathbf{v} \boldsymbol{v}$
}

1 Serviço Nacional de Aprendizagem Industrial Cimatec, Núcleo de Gestão de Pessoas. Salvador, BA, Brasil.

2 Serviço Nacional de Aprendizagem Industrial Cimatec, Núcleo de Graduação, Mestrado Profissionalizante em Gestão e Tecnologia Industrial. Av. Orlando Gomes, 1845, Piatã, 41650-010, Salvador, BA. Correspondência para/Correspondence to: C.S. PEREIRA-GUIZZO. E-mail: <camila.pereira@fieb.org.br>.

Article based on the master thesis of J.R.S. CÂMARA, intitled: "Valores relativos ao trabalho e valores organizacionais na perspectiva de professores universitários: um estudo correlacional". Serviço Nacional de Aprendizagem Industrial Cimatec; 2010. 
Participaram da pesquisa 68 professores de uma instituição de ensino superior focada em inovação. Os resultados mostraram que Realização no Trabalho obteve média mais elevada; Relações Sociais apresentou correlações com os valores organizacionais Autonomia $(p=0.018)$, Realização $(p=0.001)$, Domínio $(p=0.048)$, Prestígio $(p=0.001)$, Conformidade $(p=0.016)$ e Preocupação com a Coletividade $(p=0.014)$. Esses resultados sugerem a importância dos valores para a satisfação laboral e para a elaboração de estratégias organizacionais.

Palavras-chave: Criatividade; Ensino superior; Inovação; Satisfação no trabalho; Clima organizacional.

There are several theories to study human values. One widely accepted theory in the scientific community is Schwartz's theory. In general, Schwartz (2005) states that the values are characterized as follows: values are beliefs and a motivational construct; values transcend situations and actions; values guide the selection and evaluation of actions, people and events; and values are ordered by their importance. However, Schwartz's theory brings a significant contribution when presenting a framework for understanding these values, which has been recognized and tested in different cultures (Schwartz \& Sagie, 2000). It is a unifying theory in the field of human motivation able to organize various reasons, needs and objectives proposed in other theories.

According to Schwartz's theory (Schwartz, 2005), there are ten motivationally distinct types of values alongside with their goals that tend to be universal: (1) Power: social status and prestige, control or dominance over people and resources; (2) Achievement: personal success through demonstrating competence according to social standards; (3) Hedonism: pleasure and sensuous gratification for oneself; (4) Stimulation: excitement, novelty, challenge in life; (5) Self-Direction: independent thought and action-choosing, creating, exploring; (6) Universalism: understanding, appreciation, tolerance and protection for the welfare of all people and for nature; (7) Benevolence: preservation and enhancement of the welfare of people with whom one is in frequent personal contact; (8) Tradition: respect, commitment and acceptance of the customs, and ideas that traditional of culture or religion provides; (9) Conformity: restraint of actions, obedience, inhibition of actions or inclinations that might harm others and violate social norms; (10) Security: safety, harmony and stability of society, of relationships,

260 and of itself (Schwartz \& Sagie, 2000).
According to the author "this structure derives from the fact that actions in the pursuit of any value have consequences that may conflict or be congruent with the pursuit of other values" (Schwartz, 2005, p.28). In this perspective, the ten motivational types can be further classified into four motivational types of second order: Self-enhancement (Power, Achievement and Hedonism) versus Self-transcendence (Universalism and Benevolence), Openness to Change (Self-Direction, Stimulation and Hedonism) versus Conservation (Tradition, Conformity and Security) (Schwartz \& Sagie, 2000).

Although related to this comprehensive framework of basic values, every context of life can present specific values requiring, in turn, alternative methods for understanding specific behaviors. Thus, the theory of human values proposed by Schwartz has inspired Brazilian researchers to investigate specific values within the context of work and organization (Oliveira \& Tamayo, 2004; Porto \& Tamayo, 2003; Tamayo, 1998; Tamayo \& Gondim, 1996).

At the organizational level, to understand culture and recognize its influence on the behavior of workers, first values must be evaluated as they are important components of the identity of a business (Tamayo, 1998). According to Tamayo and Gondim (1996, p.63), organizational values are characterized as "hierarchically organized principles or beliefs related to the type of structure or models of desirable behavior that guide the life of the business and are at the service of individual, collective or mixed interests".

Bedani (2012) investigated the influence of organizational values on stimuli and barriers to creativity in the work environment at a financial institution. The results of their study showed that the organizational value of autonomy emerged as the best predictor of both organizational support 
for and resistance to new ideas. Organizational values, such as concern for community, realization, and conformity, were positively related to support new ideas, whereas the relationship with tradition and mastery was negative. The authors found that the work context must favor autonomy, the overcoming of conservatism, tolerance, equality in relationships with employees, competence, success, courtesy, and respect in work relationships to foster creative processes. The study concluded that organizational values play an important role in the expression of creativity in workers.

Canova and Porto (2010) conducted a study with teachers in secondary schools with the purpose of identifying the impact of organizational values on occupational stress since creativity is required for the teachers' intellectual development and students' involvement. The researchers found that teachers who reported stronger organizational values of autonomy, well-being, ethics and concern with the community reported less occupational stress. The authors concluded that organizational values significantly influence the occupational health of teachers.

Cantos, Silva, and Nunes (2005) conducted a study with university professors at a public Brazilian institution of higher education to verify the sources of stress and construct a picture of the working conditions of professors and their impact on health. The results were similar to the results of studies conducted in European countries: one of the main causes of stress was an overload of work (activities, meetings, workload, demands, responsibilities, end-of-semester requirements and deadlines). Another cause of stress was the lack of time to perform all of the required responsibilities, which led to frustration, fatigue, disagreement, competition and disharmony. These negative aspects were associated with negative health effects on the professors, such as depression, lack of stimulation, stress and individualism.

Even if the work demands are high, other studies have revealed the positive aspects of teaching in higher education. Novo et al. (2010) conducted a study with university professors at a Brazilian federal university and confirmed that work is valued more than the financial return; it offers self-fulfillment, social inclusion and recognition, prestige, status, and a sense of usefulness. Some university professors reported pride in their professional activity because they believe that their profession requires a high level of knowledge and demands intellectual development, which generates recognition from society. The university professors felt rewarded when their students were appointed to important positions, accepted into graduate schools, or performed well on public service exams. These professors also reported a feeling of realization in knowing that their work may contribute to a better world.

The meaning of teaching can be related to the values or rewards that university professors seek throughout their professional activity. Thus, the meaning of work can be analyzed by applying the theory of values (Ros, Schwartz, \& Surkiss, 1999). Porto and Tamayo (2003) characterize work-related values as "principles or beliefs about goals or desirable rewards, hierarchically organized, which people seek through work and that guide their evaluation of the results and context of work" (p.146). Ros et al. (1999) conducted a preliminary quantitative study of the theory of work values and identified a four-factor structure: intrinsic - goals obtained through the content of their own work; extrinsic - goals obtained through the results of the work; social - relational goals; and prestige - the search for power and prestige through work.

For Masetto (2003), the requirements for professors' training have changed: professors are required to have unique skills to influence learning, produce knowledge and disseminate knowledge. It is also the responsibility of professors to promote the development of new techniques and technologies in different sectors (Arbix, 2010; Fava-de-Moraes, 2000). Figure 1 summarizes the main justifications related to the importance of the study involving professors.

As shown in Figure 1, the professor is responsible for research, service activities and 
teaching. An environment with an appropriate, positive organizational atmosphere that supports teaching activities can create conditions that are more conducive to the creativity of professors and students, thus fostering innovation. Martín, Orengo, and Martínez (1997) explained that creativity is the capacity of a professional to generate original and useful ideas, which is a crucial component for innovation. Although there are certain difficulties to overcome and gaps to be filled in the adoption of innovative strategies in higher education, the effectiveness of educational activities can impact the training of highly qualified professionals who become more prepared and confident to make choices, face challenges, and handle the uncertainties of professional performance when they enter the labor market, either as formal employees or entrepreneurs.

All of these arguments reinforce the importance of university professors in society, either as facilitators of the learning process for future professionals or as those who stimulate and motivate research and encourage innovation. The present research can also contribute to theoretical and methodological issues to the extent that it examines the values in a context that focuses on innovation, stimulating the production of knowledge in an area that still needs to find convergences and interdisciplinary dialogue, as

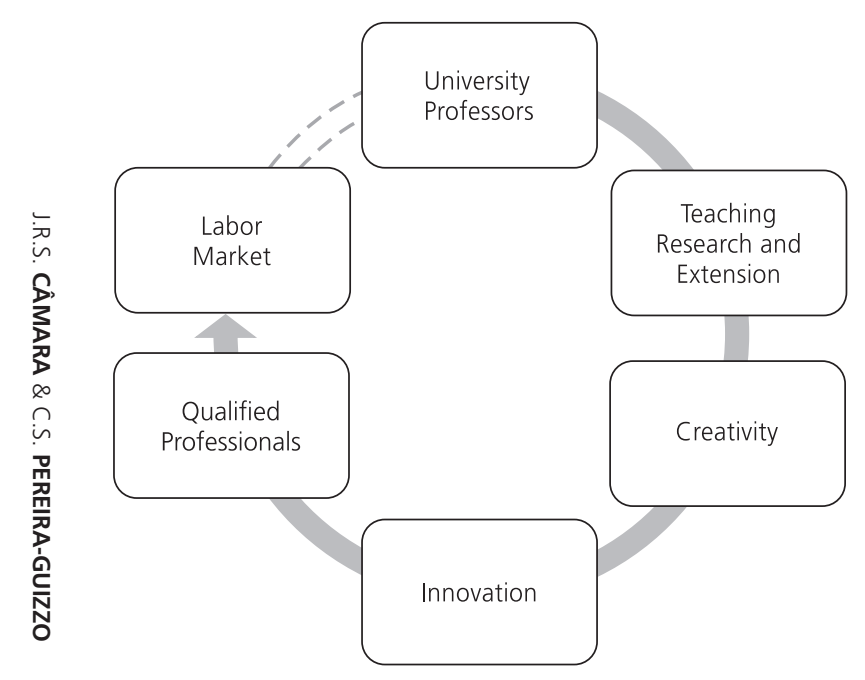

Figure 1. University professors' contributions to professional training 262 and innovation. suggested by Bruno-Faria and Vargas (2013). Thus, the aims of the present study were (a) to evaluate the values related to teaching; and (b) to analyze the relationship between work-related values and organizational values from the perspective of university professors.

\section{Method}

\section{Participants}

To be included in this study, participants were required to (a) teach classes at a higher education institution; (b) possess at least a Specialist Diploma; and (c) be working at the university for at least three months. To determine the sample size, we used a confidence level of $95 \%$ and a $5 \%$ significance level. This calculation indicated that 68 participants were required to meet the confidence and significance parameters of the study.

Thus, the sample for this study consisted of 68 university professors, being $71 \%$ male and 29\% female, aged 27 to 63 years, with a mean age of 40 years. The majority $(62 \%)$ of the respondents were married. In terms of education, all of the participants had at least a graduate-level degree (56\% master's and 25\% doctoral degree). The majority of the participants had undergraduate degrees in Exact Sciences or Technology (78\%) and $82 \%$ also had a graduate degree in Exact Sciences or Technology.

The study was conducted at a private institution of higher education with courses in the field of Technology and Exact Sciences. The institution is recognized by the Ministry of Education (MEC) and has been accredited since 2004. It offers undergraduate courses and graduate programs and it is located in the state of Bahia, Brazil. At the time of this study, there were approximately 420 students enrolled and 11 undergraduate courses. The staff consisted of approximately 120 persons, of which 82 were professors (hired until the end of 2011). It is important to point out that the institution has stated the following values in its documents: ethics and transparency, social responsibility, valorization of people, client satisfaction, and innovation. 


\section{Instruments}

The instruments chosen to measure the variables of interest in this research corresponded to the expectations of validation in Brazil with a sample of professionals in higher education, specific work contexts, and organization and reasoning in the theory of human values proposed by Schwartz. The instruments chosen understood:

\section{Scale of Work-Related Values}

The Scale of Work-Related Values (SWV) is an instrument based on the theory of values by Schwartz developed by Porto and Tamayo (2003) and designed for the work context. The instrument has shown good reliability and has been validated in the Brazilian context through a sample of employees of different professions and hierarchical levels. It is composed of 45 items grouped into four factors, over 3 eigenvalues, satisfactory accuracy rates, and KMO test of 0.90 . The factors are as follows: (1) realization at work, the search for pleasure, stimulation and independence of thought and action in work (15 items; $\alpha=0.88$ ); (2) social relationships, the search for positive social relationships at work and the opportunity to contribute to society through work (12 items; $\alpha=$ $0.88) ;(3)$ prestige, the search for the ability to influence other people and succeed at work (11 items; $\alpha=0.87$ ); and (4) stability, the search for security and financial stability through work (7 items; $\alpha=0.81$ ). The participants evaluated the importance of the 45 items, classifying each statement on a scale from 1 to 5 (1 not important; 2 slightly important; 3 important; 4 very important; and 5 extremely important).

\section{Inventory of Organizational Values Profile}

This instrument was constructed and had previously been validated with a large sample of employees from Brazilian public and private companies by Oliveira and Tamayo (2004). Based on Schwartz's theory (2005), the instrument is composed of 48 items that describe a hypothetical organization. The possible responses are as follows: "it is very similar to my organization; it is similar; it is more or less similar; it is slightly similar; it is not similar to my organization; there is nothing similar between this organization and mine" (Oliveira \& Tamayo, 2004, p. 134). The Inventory of Organizational Values Profile (IOVP) has satisfactory psychometric qualities and allows the evaluation of eight factors: (1) autonomy, which represents the aim for constant improvement among employees, products and services that is expressed through competence, innovation, creativity, definition of employees' professional goals, and valorization of challenges ( 8 items; $\alpha=0.87$ ); ( 2 ) well-being, which represents the concern of the organization with employee satisfaction and attention to the quality of life at work (6 items; $\alpha=0.87$ ); (3) realization, which represents success, based on demonstrations of competence, organization and collaborators ( 5 items; $\alpha=0.80$ ); (4) mastery, which represents status, income and a dominant position in the market (6 items; $\alpha=0.80$ ); (5) prestige, which represents the organization's quest for prestige, admiration and respect from society based on the quality of its products and services ( 4 items; $\alpha=0.81$ ); (6) conformity, which represents the importance given by the organization regarding the respect for rules and behavior models (courtesy, good manners, respect for rules of companionship, correction and hierarchy), both in the work environment and relationships with other organizations (7 items; $\alpha=0.75$ ); (7) tradition, which represents the emphasis that the organization places on maintaining the status quo, preserving and respecting purposes, customs and organizational practices ( 5 items; $\alpha=0.75$ ); and (8) concern with community, places value on equality, justice, loyalty, honesty and sincerity in organizational practices and norms of conduct adequate to organizational collectivity (individuals, organizational sectors, community, clients and suppliers) (7 items; $\alpha=0.86$ ).

\section{Procedures}

Potential participants received an e-mail inviting them to participate in the present study. The form of informed consent, the SWV and IOVP were given to the individuals interested in 
participating in the study. Some participants responded the instruments as soon as they received the information about the study and gave consent to participate. However, the majority of participants preferred to take the questionnaires home for more reading comfort and returned them after approximately five days.

The responses obtained in this study were tabulated quantitatively and analyzed using descriptive statistics (mean, median and standard deviation) and inferential statistics (Spearman's correlation test). The SWV and IOVP scores were analyzed considering the items and factors. A normality test was performed to verify whether the assumptions required for parametric statistics were met. However, the results indicated that the data were not normally distributed and thus, nonparametric statistics were used. In this case, Spearman's correlation test was used to investigate the relationship between the SWV and IOVP factors, establishing the level of significance at $p<0.05$. The data were analyzed using the Statistical Package for Social Sciences (SPSS) for Windows 19.0.

Another important aspect of the method is related to ethics. The present study was guided by the precepts of Resolution $n^{\circ} 196 / 1996$ of the Brazilian National Health Council and it was analyzed and approved by the Research Ethics Committee for Human Studies of the Secretary of Health of the State of Bahia, Brazil (n 094/2011, December 5, 2011).

\section{Results}

The descriptive analysis revealed the hierarchy of work-related values according to the university professors. Table 1 shows these results.

As shown in Table 1, the professors mostly valued Realization at work. In order of rank, the other factors were Stability, Social Relationships and, finally, Prestige. Table 2 shows the significant correlations between the SWV and IOVP factors.

The Social relationships factor from the SWV had a positive correlation with the IOVP factors of Autonomy ( $r=0.286 ; p=0.018)$, Realization ( $r=0.385$; $p=0.001)$, Mastery $(r=0.241 ; p=0.048)$, Prestige $(r=0.419 ; p=0.001)$, Conformity $(r=0.291 ; p=0.016)$ and Concern with community $(r=0.298 ; p=0.014)$. The SWV factor Prestige had positive correlations with the organizational values of Autonomy $(r=0.305$; $p=0.011)$, Mastery $(r=0.266 ; p=0.028)$ and Tradition $(r=0.244 ; p=0.045)$. The work-related value of Stability had a significant positive correlation with the organizational values of Mastery $(r=0.273$; $p=0.024)$ and Tradition $(r=0.306 ; p=0.011)$.

Table 1

Descriptive analysis of Scale of Work-Related Values factors

\begin{tabular}{lccc}
\hline Factors & Mean & Median & Standard Deviation \\
\hline Realization at work & 4.4 & 4.5 & 0.4 \\
Stability & 4.1 & 4.1 & 0.6 \\
Social relationships & 3.5 & 3.5 & 0.5 \\
Prestige & 2.6 & 2.5 & 0.6 \\
\hline
\end{tabular}

Table 2

Significant correlations among the Scale of Work-Related (SWV) Values and Inventory of Organizational Values Profile (IOVP) factors

\begin{tabular}{|c|c|c|c|c|}
\hline SWV IOVP & Realization at Work & Social Relationships & Prestige & Stability \\
\hline Autonomy & ns & $0.286^{*}$ & $0.305^{*}$ & ns \\
\hline Well-being & ns & ns & ns & ns \\
\hline Realization & ns & $0.385^{* *}$ & ns & ns \\
\hline Mastery & ns & $0.241^{*}$ & $0.266^{*}$ & $0.273^{*}$ \\
\hline Prestige & ns & $0.419^{* *}$ & ns & ns \\
\hline Conformity & ns & $0.291^{*}$ & ns & ns \\
\hline Tradition & ns & ns & $0.244^{*}$ & $0.306^{*}$ \\
\hline Concern with community & ns & $0.298^{*}$ & ns & ns \\
\hline
\end{tabular}

Note: ${ }^{*} p<0.05 ;{ }^{* *} p<0.01$.

264

ns: not significant. 
Considering these results, it is noteworthy that the work-related value of Social relationships was the only factor that was correlated with six of the eight factors related to organizational values.

Table 2 also shows that there were no significant correlations between the Realization at work factor (SWV) and the factors in the IOVP. To reinforce this aspect, of the four factors that compose the SWV, only Realization at work was not correlated with any factor in the IOVP.

With regard to organizational values (IOVP), the Mastery factor was correlated with three of the four factors that compose the SWV. Only the WellBeing factor was not correlated with any of the factors in the SWV.

\section{Discussion}

The aim of the present study was to evaluate the work-related values of university professors as well as to analyze the relationship between those values and the organizational values of a higher education institution focused on innovation. According to Porto and Tamayo (2003), the emphasis on the Realization at work factor demonstrates that the search for pleasure, stimulation and independence of thought and action in work is the main force that guides the actions of the professors in this study. This result is in agreement with the study conducted by Novo et al. (2010) on the meaning of work for professors in which they also reported that work was important because it generated a feeling of usefulness, pleasure, and professional accomplishment. These results are also in agreement with other researchers such as Schwartz and Sagie (2000), who identified the importance of the values of achievement and universalism for professors from different countries.

Notwithstanding the importance of Realization at work in the sample, the Spearman analysis did not indicate a significant relationship between this SWV factor and the organizational values investigated using the IOVP. Realization at work may be an intrinsic value related to goals associated with the content of the work itself (Ros et al., 1999). Thus, it is believed that if professors have an interest in this type of work and receive professional satisfaction from it, they may be more strongly committed to teaching, producing knowledge, and developing innovation and technology for the productive sector (Bedani, 2012; Bouwkamp-Memmer, Whiston, \& Hartung, 2013; Elizur \& Koslowsky, 2001).

Stability was the second most important value identified in the SWV. Stability refers to the search for security and financial stability through work (Porto \& Tamayo, 2003). Accordingly, there was a relationship between the Stability factor and the organizational values of Mastery and Tradition. The relationship between these values may show that the more an organization values Mastery (status, income and dominant position in the market) and Tradition (the preservation of the customs and practices of the organization), the stronger may be the feelings of security and stability among the university professors. In fact, perceiving that the institution is guaranteeing their competitiveness and survival during an unstable economic time can promote a feeling of job security. The association of these variables can also be an interesting finding for the organization to maintain their stated values, Client Satisfaction and Innovation, to the extent that the organization supports the constant search for modern solutions and its needs with the purpose of increasing competitiveness and capacity of its partners.

Social relationships was the third value in the hierarchy of importance in the SWV. According to Porto and Tamayo (2003), this value represents the search for positive social relationships in the organizational environment and the desire to contribute to society through work. This result is in agreement with the observations of authors who have emphasized the importance of satisfactory social relationships in the work context and surroundings that can produce an environment conducive to productivity and occupational health (Canova \& Porto, 2010; González, Corte, \& León Rubio, 2010).

It is interesting to note that Social relationships showed the greatest number of 
significant correlations with organizational values (IOVP): Autonomy, Realization, Mastery, Prestige, Conformity and Concern with Community. This result reinforces the importance of strengthening the work-related value of Social Relationships, which contributes to the general value of selftranscendence (universalism and benevolence) if these variables improve the organizational atmosphere, stimulate cooperation, promote justice and relationships at work, and increase tolerance and honesty, as suggested by Canova and Porto (2010), Costa, Roe, and Taillieu (2001), Oliveira and Tamayo (2004), Ros et al. (1999), Schwartz (2005), and Teixeira and Pereira (2008). These results also suggest that actions to strengthen social relations in the organization studied can sustain compliance with the values stated in institutional documents of Ethics and Transparency, Social Responsibility, and Valorization of People.

To further illustrate the need to align work-related values with organizational values to maintain commitment, motivation and innovation, we quote the words of Canova and Porto (2010, p.23):

Professors, considered professionals with a high predisposition to help others, care for their students with the objective of training them and integrating them into society; the more they perceive that the organization values the community and therefore, there is a consonance with their desires, the less they perceive occupational stress.

Arbix (2010) also describes a development strategy: "an environment based on high-quality human resources, tolerance, the continuous flow of ideas and information without prejudice, and particularly entrepreneurial friendliness is more conducive to innovation" (p.171). In addition, King and Gurland (2007) found that autonomous orientation was related to detail and complexity in a creative task and participants felt less competent performing a task under the threat of evaluation. Thus, social relationships can be seen as an important condition for promoting creativity in the

266 work environment and should be considered when selecting innovation strategies in accordance with personal and environmental factors, which have previously been shown to influence this process (Alencar, 1998; Bedani, 2012; King \& Gurland, 2007; Shalley, Zhou, \& Oldham, 2004; Yi, Hu, Plucker, \& McWilliams, 2013).

Prestige was the lowest in the SWV values. This value refers to the search for influence over other people and success at work (Porto \& Tamayo, 2003). Success and power were not emphasized by the participants in this sample and this result may be beneficial for the development of trust among colleagues, cooperation at work and teamwork, as Costa et al. (2001) suggest. Although there might not be a consensus, studies show that interpersonal conflict and organizational atmosphere created in a highly competitive environment through the search for prestige can cause negative effects on people, such as lack of trust, hostility, intimidation, pressure, lack of support and even creative inhibition (Alencar, 1998; Alencar \& Fleith, 2008; Yi et al., 2013; Zhou \& George, 2001).

The analysis of the correlation indicates that there was a significant relationship between the Prestige factor and the organizational values of Autonomy, Mastery and Tradition. This result may suggest that the greater the valorization of success and self-promotion at work, the more professors perceive that the institution offers challenges and stimulates curiosity, creativity and innovation, maintains strategies and customs, and offers income and competitiveness. This result may be supported by the extrinsic values associated with the results of work and obtaining rewards (Ros et al., 1999). The relationship of these variables may also corroborate the reported values in institutional documents, especially valorization of people, understood as the employee participation in the management process with the objective of recovering the need of self-realization.

Thus, different actions can be developed from the practical implications of the results found in the present study: promoting autonomy, involving professors in decisions that matter to them, recognizing the workforce, and strengthening relationships at 
work. Although this study has practical implications, some limitations must be noted. The research was conducted in a single institution in one city. The generalization of the results may be limited because culture encompasses knowledge, beliefs, morals, customs and all of the habits of the region, as well as the organization in which the individual works. Furthermore, this type of research only indicates the existence of an association among the variables investigated and not a causal relationship. We recommend further studies with broader samples in other private and public higher education institutions in other cities and regions of the country.

\section{References}

Alencar, E. M. L. S. (1998). Promovendo um ambiente favorável à criatividade nas organizações. Revista de Administração de Empresas, 38(2), 18-25.

Alencar, E. M. L. S., \& Fleith, D. S. (2008). Criatividade pessoal: fatores facilitadores e inibidores segundo estudantes de engenharia. Magis, 1(1), 113-126.

Arbix, G. (2010). Estratégias de inovação para o desenvolvimento. Revista de Sociologia da USP, 22(2), 167-185.

Bedani, M. (2012). O impacto dos valores organizacionais na percepção de estímulos e barreiras à criatividade no ambiente de trabalho. Revista de Administração Mackenzie, 13(3), 150-176.

Bouwkamp-Memmer, J. C., Whiston, S. C., \& Hartung, P. J. (2013). Work values and job satisfaction of family physicians. Journal of Vocational Behavior, 82(3), 248-255.

Bruno-Faria, F., \& Vargas, E. R. (2013). Inovação, criatividade e empreendedorismo. Revista Psicologia, 13(3), v-vi.

Canova, K. R., \& Porto, J. B. (2010). O impacto dos valores organizacionais no estresse ocupacional: um estudo com professores de ensino médio. Revista de Administração Mackenzie, 11(5), 4-31.

Cantos, G. A, Silva, M. R., \& Nunes, S. R. L. (2005). Estresse e seu reflexo na saúde do professor. Saúde em Revista, 7(15), 15-19.

Costa, A. C., Roe, R. A., \& Taillieu, T. (2001). Trust within teams: The relation with performance effectiveness. European Journal of Work Organizational Psychology, 10(3), 225-244.

Elizur, D., \& Koslowsky, M. (2001). Values and organizational commitment. International Journal of Manpower, 22(7), 593-599.
Fava-de-Moraes, F. (2000). Universidade, inovação e impacto socioeconômico. São Paulo em Perspectiva, 14(3), 8-11.

González, A. M. C., Corte, C. M. C., \& León Rubio, J. M. (2010). Engagement: Un recurso para optimizar la salud psicosocial en las organizaciones y prevenir el burnout y estrés laboral. Revista Digital de Prevención. Recuperado en Julio 30, 2012, de: http://rabida.uhu. es/dspace/bitstream/handle/10272/5468/Engagement_ un_recurso_para_optimizar_la_salud_psicosocial. pdf? sequence $=2$

King, L., \& Gurland, S. T. (2007). Creativity and experience of a creative task: Person and environment effects. Journal of Research in Personality, 41(6), 1252-1259.

Martín, P., Orengo, V., \& Martínez, I. M. (1997). Innovación y creatividad en las organizaciones: Perspectivas de análisis. Revista de Psicología del Trabajo y de las Organizaciones, 13(1), 99-118.

Masetto, M. T. (2003). Competência pedagógica do professor universitário. São Paulo: Summus.

Novo, L. F., Almeida, R. S., Pinto, R. S., Silva, J. S., Cantos, L. C., \& Moraes, M. G. F. (2010). O significado do trabalho para os docentes de uma ifes: um contributo à área de gestão de pessoas. In X Coloquio Internacional Sobre Gestión Universitaria En América Del Sur, Mar Del Plata, 10 Dec. 2010. Recuperado em janeiro 17, 2012, de: http://www.inpeau.ufsc.br/wp/wp-content/ BD_documentos/coloquio10/199.pdf

Oliveira, Á. F., \& Tamayo, A. (2004). Inventário de perfis de valores organizacionais. Revista de Administração da USP, 39(2), 129-140.

Porto, J. B., \& Tamayo, A. (2003). Escala de valores relativos ao trabalho - EVT. Psicologia: Teoria e Pesquisa, 19(2), 145-152.

Ros, M., Schwartz, S. H., \& Surkiss, S. (1999). Basic individual values, work values, and the meaning of work. Applied Psychology: An International Review, 48(1), 49-71.

Schwartz, S. H., \& Sagie, G. (2000). Value consensus and importance: A cross-national study. Journal of Cross-cultural Psychology, 31(4), 465-497.

Schwartz, S. H. (2005). Valores humanos básicos: seu contexto e estrutura intercultural. In A. Tamayo \& J. B. Porto (Eds.), Valores e comportamento nas organizações (pp.21-55). Petrópolis: Vozes.

Shalley, C. E., Zhou, J., \& Oldham, G. R. (2004). The effects of personal and contextual characteristics on creativity: Where should we go from here? Journal of Management, 30(6), 933-958.

Tamayo, A. (1998). Valores organizacionais: sua relação com satisfação no trabalho, cidadania organizacional e comprometimento afetivo. Revista de Administração, 33(3), 56-63. 
Tamayo, A., \& Gondim, S. M. G. (1996). Escala de valores organizacionais. Revista de Administração Contemporânea, 31(2), 62-72.

Teixeira, M. L. M., \& Pereira, E. L. (2008). Compatibilidade entre indivíduos e organização: uma proposta com base na teoria de valores de Schwartz. In M. L. M. Teixeira (Ed.), Valores humanos \& gestão: novas perspectivas (pp.339-362). São Paulo: Senac.

Yi, X., Hu, W., Plucker, J. A., \& McWilliams, J. (2013). Is there a developmental slump in creativity in China?
The relationship between organizational climate and creativity development in Chinese adolescents. The Journal of Creative Behavior, 47(1), 22-40.

Zhou, J., \& George, J. M. (2001). When job dissatisfaction leads to creativity: Encouraging the expression of voice. Academy of Management Journal, 44(4), 682-696.

Received: August 21, 2013

Final version: January 27, 2014

Approved: April 11, 2014

268 